Proc. Estonian Acad. Sci. Biol. Ecol., 2005, 54, 3, 230-241

\title{
Smelt (Osmerus eperlanus L.) in the Baltic Sea
}

\author{
Heli Shpilev ${ }^{\mathrm{a}}$, Evald Ojaveer ${ }^{\mathrm{b}}$, and Ain Lankov ${ }^{\mathrm{a}}$ \\ a Pärnu Field Base, Estonian Marine Institute, University of Tartu, Vana Sauga 28, 80031 Pärnu, \\ Estonia \\ ${ }^{\mathrm{b}}$ Estonian Marine Institute, University of Tartu, Mäealuse 10a, 12618 Tallinn, Estonia; \\ e.ojaveer@ness.sea.ee
}

Received 6 September 2004, in revised form 1 December 2004

\begin{abstract}
Smelt, a cold-water anadromous fish, has well adapted to the conditions in the brackish Baltic Sea and has formed local populations. The species is common in coastal waters but the most important marine smelt stocks are confined to the areas where the water of low temperature and relatively high oxygen content persists year round, in the neighbourhood of large estuaries and lagoons. The abundance of smelt is higher in the northern and eastern Baltic: in the Gulf of Bothnia, eastern Gulf of Finland, Gulf of Riga, and Curonian Lagoon. Smelt populations of these areas differ in growth rate, maturation, reproduction conditions, abundance and catch dynamics, etc. Smelt reproduction depends on temperature, it starts and finishes earlier in the southern areas than in the north. The growth rate of the fish is higher in the south and decreases towards north. In the Gulf of Riga the size of younger smelt has increased since the end of the 1960s. However, beginning with the early 1990s the weight of older fish has declined.
\end{abstract}

Key words: smelt stocks, abundance dynamics, growth, reproduction.

\section{INTRODUCTION}

European smelt Osmerus eprlanus L. populates brackish waters in the Baltic Sea. It spawns in rivers, bights, and inlets of low salinity. The habitats of the largest marine smelt populations are situated in the areas where well aerated water of low temperature persists year round - in the Gulf of Bothnia, eastern Gulf of Finland, and Gulf of Riga where no permanent halocline exists. An abundant smelt population also exists in the Curonian Lagoon and the adjacent coastal area of the Baltic Proper (Fig. 1). The species is common in the coastal waters, especially in estuarine regions, generally at depths up to $90 \mathrm{~m}$. In the

\footnotetext{
* Corresponding author, heli@solo.delfi.ee
} 
southern and southwestern Baltic smelt is relatively less abundant, with comparatively larger stocks in the Gulf of Gdansk, Pomeranian Bay, and the Darss-Zingst area (Winkler, 1996; Draganik, 1997; Psuty-Lipska \& GarbacikWesołowska, 1998). In deep areas of the open Baltic smelt is virtually absent. However, Draganik (1997) reports that in winter smelt has been caught also in the Slupsk Furrow and the Bornholm Basin. Generally, the larger smelt stocks inhabiting the sea areas of certain hydrological regime are separated from each other and live in different conditions. Their adaptation to the specific conditions has been expressed as the evidence of homing (e.g. Hudd, 1985). The economic importance of smelt is moderate. Usually it is fished on its spawning grounds and as bycatch in fisheries directed to other species. In the northern Quark the species is caught chiefly for animal fodder (Hudd, 1985). However, in some areas of the Baltic Sea smelt is fished as a traditional item of human food having a circle of consumers established during centuries. The Russian scribe book of the 15th16th centuries states that in the eastern Gulf of Finland (the region of the Koporye River) smelt was one of two main food fishes (Kraikovski et al., 2004).

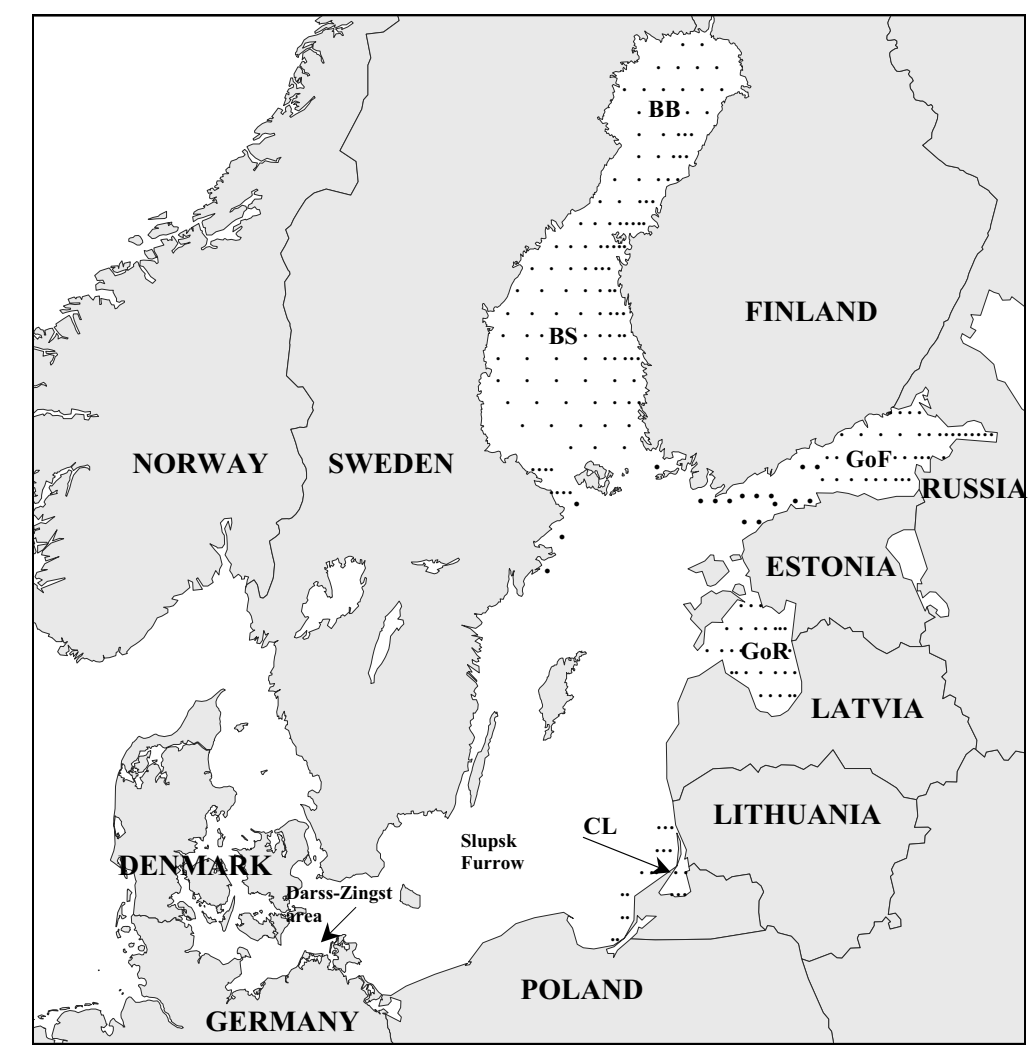

Fig. 1. Main stocks of smelt in the Baltic Sea (BB - Bothnian Bay, BS - Bothnian Sea, GoF - Gulf of Finland, GoR - Gulf of Riga, CL - Curonian Lagoon). 


\section{MATERIAL AND METHODS}

The work is based on long-term studies of smelt in Estonian waters and the literature data on smelt in other regions of the Baltic Sea. The bulk of data on smelt in the Estonian waters stem from the Gulf of Riga. Regular biological analyses (100 individuals each, length and weight measured, age, sex, maturity, and food composition studied) were weekly collected from the specialized trapnet fishery on the spawning grounds in the Pärnu River and Pärnu Bay during 1957-2003 (a total of 30000 individuals). Monthly samples were taken from trawl catches in feeding areas in the Gulf of Riga (about 10000 smelt) during the fishing season and also from experimental catches. The annual length and weight of individuals in age groups were calculated as the arithmetic means from monthly data. For the growth data, the average total length and weight of smelt age groups were calculated on the basis of the material sampled from smelt spawning stock (equal sampling on the spawning grounds from March to May). Detailed investigations on the feeding of smelt were conducted in 1960-1962 and 19941998. The year-class abundance was taken from the VPA run on the Gulf of Riga smelt stock in 1964-1995. The annual larval abundance was estimated as the average from the data of weekly 10-min hauls with Hensen net in Pärnu Bay (3 stations, from May to the end of June, 1964-2002) and in the Pärnu River (3 stations, 1990-2002). Smelt shoals on the feeding grounds in the Gulf of Finland were investigated based on samples taken from pelagic trawl fishery in the 1970s-1980s. The material for morphometric studies $(n=71)$ was taken from gillnet catches of spent smelt in Pärnu Bay in spring 1993. The measurements and material treatment were performed according to Pravdin's (1939) methods.

\section{RESULTS AND DISCUSSION}

\section{Stocks}

It was stated long ago that smelt is a polymorphic species with considerable morphological variability (Benecke, 1881). Its adaptation to various environments has resulted in the formation of local populations with different morphological characters, growth rate, and maturation time. Studies on the structure of the smelt stock in the Gulf of Riga have shown that it is rather homogeneous and no significant differences have been found between males and females. Also, literature data do not suggest the existence of clear heterogeneity in the smelt stock in the Northern Quark, Gulf of Bothnia. Based on tagging results, Hudd (1985) believes that in this area there are separate small intermingling spawning communities. He treats them together as one unit stock. However, in the eastern Gulf of Finland, Kozhevnikov (1949) differentiated the "shallow water form" constantly living in the shallow coastal zone and the "deep water smelt" populating after spawning deeper areas. Popov (1978) argues that these two ecological groups differ from each other in the time of sexual maturation, length of life, and growth rate, as the feeding conditions of the "shallow water form" are clearly worse than those of 
the "deep water group". In the Curonian Lagoon one smelt group migrates after spawning into the coastal areas of the open sea whereas another group lives constantly in the lagoon (Benecke, 1881; Noskova, 1968; Mištautaite, 1973). It has been suggested that the lagoon group represents a freshwater form of the smelt $O$. eperlanus eperlanus $m$. spirinchus Pallas and the two forms are morphologically different (Mištautaite, 1973). Because of methodological differences in the morphological investigations and treatment of data on smelt of the Gulf of Riga, eastern Gulf of Finland, and Curonian Lagoon, the estimation of the significance of differences in smelt morphology between the areas (Table 1) is problematic. However, application of Pravdin's (1939) method for the estimation of differences between the morphological features allows us to state that between the smelt of the eastern Gulf of Finland and the Curonian Lagoon real differences exist in the length of dorsal fin and the number of vertebrae (Table 1). Also, it has been found that in the marine smelt of the Curonian Lagoon (Mištautaite, 1973) and of the Gulf of Riga (H. Shpilev, unpubl. data), clear sexual dimorphism is absent. However, Popov (1977) found that in smelt of the eastern Gulf of Finland some difference between the sexes exists in body depth in the prespawning period. This finding should be confirmed by studies of this feature in smelt in their feeding period to eliminate the influence of the gonadosomatic index, which probably significantly differs in male and female individuals in later stages of sexual maturity.

Table 1. Morphological features of smelt in the prespawning stage in the Gulf of Riga (Pärnu Bay, 1993, $n=71$ ), the eastern Gulf of Finland $(1974, n=151$ ), and the Curonian Lagoon (marine smelt, $1968, n=52$ )

\begin{tabular}{|c|c|c|c|c|}
\hline Character & \multicolumn{2}{|c|}{$\begin{array}{l}\text { Gulf of Riga } \\
\bar{x}, \text { range }\end{array}$} & $\begin{array}{c}\text { Gulf of Finland } \\
\bar{x} \pm \mathrm{SE} \\
\end{array}$ & $\begin{array}{c}\text { Curonian Lagoon } \\
\bar{x} \pm \mathrm{SE} \\
\end{array}$ \\
\hline \multicolumn{5}{|l|}{ Plastic characters: } \\
\hline \multicolumn{5}{|l|}{$\%$ of fork length } \\
\hline Length of dorsal fin & 9.48 & $(8.20-12.75)$ & $8.73 \pm 0.05$ & $8.3 \pm 0.09$ \\
\hline Length of pectoral fin & 14.53 & $(12.17-19.70)$ & $14.58 \pm 0.05$ & $14.38 \pm 0.12$ \\
\hline Length of anal fin base & 13.36 & $(11.41-16.04)$ & $12.68 \pm 0.08$ & $12.47 \pm 0.12$ \\
\hline Length of head & 22.54 & $(20.64-24.32)$ & $21.41 \pm 0.06$ & $21.86 \pm 0.14$ \\
\hline \multicolumn{5}{|l|}{$\%$ of head length } \\
\hline Preorbital distance & 28.88 & $(25.27-31.71)$ & $31.48 \pm 0.14$ & $30.90 \pm 0.22$ \\
\hline Postorbital distance & 50.65 & $(41.71-58.26)$ & $53.25 \pm 0.12$ & $51.30 \pm 0.35$ \\
\hline Vertical diameter of eye & 19.13 & $(16.40-22.47)$ & $19.84 \pm 0.11$ & $19.84 \pm 0.28$ \\
\hline \multicolumn{5}{|l|}{ Meristic characters: } \\
\hline Spinous rays of dorsal fin & 2.50 & $(2-3)$ & $2.09 \pm 0.02$ & $2.25 \pm 0.06$ \\
\hline Soft rays of dorsal fin & 8 & $(7-9)$ & $8.38 \pm 0.05$ & $8.15 \pm 0.06$ \\
\hline Spinous rays of anal fin & 3.23 & $(3-4)$ & $3.05 \pm 0.02$ & $3 \pm 0.00$ \\
\hline Soft rays of anal fin & 12.20 & $(11-14)$ & $12.20 \pm 0.05$ & $12.35 \pm 0.09$ \\
\hline Number of vertebrae & 58.89 & $(58-62)$ & $60.12 \pm 0.06$ & $58.81 \pm 0.11$ \\
\hline
\end{tabular}


There are certain differences in the individual growth rates and spawning times of smelt in the above-named regions. The dynamics of smelt populations varies under the impact of climate variability, eutrophication/pollution, and fisheries, both by areas and time periods.

\section{Fecundity and reproduction}

The fecundity of smelt varies in wide limits and depends on the length, weight, and age of fish (Belyanina, 1966; Podarueva, 1972a, b; Popov, 1985). The dependence of the fecundity of smelt on the length and weight in Pärnu Bay spawning shoals can be expressed by the following equations (Shestakov, 1967): $\mathrm{AF}=5794 \mathrm{Fl}-68000$ and $\mathrm{AF}=677 \mathrm{Tw}+1250$, where $\mathrm{AF}$ denotes the absolute fecundity, Fl fork length, and Tw total weight. Every $10 \mathrm{~g}$ increase in the fish weight increases its fecundity by 6770 eggs in the Gulf of Riga and by 6600 eggs in the eastern Gulf of Finland (Shestakov, 1967; Popov, 1985). The AF of the smelt of Pärnu Bay is higher than in Narva Bay, eastern Gulf of Finland (Shpilev, 2003).

Usually smelt mature at the age of 2-3 years. In the Gulf of Bothnia $21 \%$ twoyear-old smelt are mature. In spawning concentrations in Pärnu Bay the share of 2-year-old smelt has increased since the mid-1990s, when the stock size started to increase. The percentage of 2-year-old fish in the spawning shoals was $27.6 \%$ in 2000 and $56.3 \%$ in 2002 . The youngest maturing smelt (males) have been one year old. In the Curonian Lagoon the common age of maturation is 2-3 years in the marine smelt and one year in the lagoon stock. In the eastern Gulf of Finland (Popov, 1978) and in the Gulf of Riga smelt mature at the age of 2-6 years. Age composition of spawning shoals depends on the dynamics of year-class abundance and the exploitation rate of the stock. In the Curonian Lagoon spawning shoals of marine smelt consist of 2-6-year-old fish (prevailing ages 3-4), in the Gulf of Riga of age groups 2-10+ (prevailing ages 3-6), and in the eastern Gulf of Finland of 1-9-year-old fish (prevailing ages 3-5). Consequently, in the Curonian Lagoon the life of marine smelt is somewhat shorter than in the populations of the northern areas of the Baltic Sea. The life of the lagoon stock is considerably shorter than in the marine population.

Smelt spawn in rivers, estuaries, and freshened inner parts of bays. In the limits of larger stocks a number of spawning shoals may exist, which mix in their feeding areas. Because of alterations in the environment (construction of dams, regulation of river runoff, eutrophication, etc.), the importance of different spawning places may have changed during the history. In the first half of the last century, the most important spawning places of the Gulf of Riga smelt were located in the Daugava River (Heinemann, 1905; Gaumiga, 1967). After damming this river lost its previous importance and now the bulk of the Gulf of Riga smelt spawn in the Pärnu River and its tributaries, as well as in the northernmost parts of Pärnu Bay. The effect of the regulation of river runoff upon the smelt stock has been various. The catches of smelt in the Curonian Lagoon clearly increased 
Table 2. Spawning of smelt in different areas of the Baltic Sea

\begin{tabular}{|c|c|c|}
\hline Stock & Spawning period & Optimum temperature, ${ }^{\circ} \mathrm{C}$ \\
\hline Curonian Lagoon & 2nd half of March-1st decade of April & $2.5-5.6$ \\
\hline Pärnu Bay & 2nd decade of March-early May & $3-6$ \\
\hline Eastern Gulf of Finland & 1st decade of May-mid-June & $4-7^{\mathrm{a}}\left(8-11^{\mathrm{b}}\right)$ \\
\hline Gulf of Bothnia & End of April/beginning of May-June & $3-4$ \\
\hline
\end{tabular}

(simultaneously the catches of other migratory fishes decreased) after the regulation of the runoff of the main smelt spawning river (Gaigalas, 1970; Gaigalas \& Mištautaite, 1980).

The timing of spawning depends on water temperature. Maturing smelt form concentrations usually in November. At the end of November and in December they start migration to the inner parts of bays, close to the spawning places where they winter. In spring, after the rise of temperature to $1-2^{\circ} \mathrm{C}$, the fish move to the spawning places. The duration of the spawning time of populations may last 1 to 6 weeks. Because of the dependence of spawning on temperature, in the Baltic Sea smelt's reproduction starts and finishes earlier in the southern regions (Popov, 1978; Gaigalas \& Mištautaite, 1980; etc.) (Table 2).

In the Pärnu River larger smelt arrive to the spawning grounds and spawn somewhat earlier than smaller individuals, but this is not the case in the Gulf of Finland where smaller individuals spawn earlier and at a lower temperature. The smallest mature smelt in the Gulf of Riga had the Fl $8.3 \mathrm{~cm}$ and the Tw $3.0 \mathrm{~g}$ (Shpilev, 2003).

\section{Growth}

Because of differences in the hydrometeorological regime in various parts of the Baltic Sea, the ecological conditions in the habitats of smelt stocks there differ. Notable differences occur in the composition and availability of food animals, in the length of the feeding period (which depends on the temperature and, in young stages, also on the time of hatching). Therefore, considerable variations exist in the growth rate of smelt in different sea areas.

It has been stated that noteworthy differences in the growth rate between the males and females are absent in the Curonian Lagoon (Gaigalas \& Mištautaite, 1980). Based on the data collected in 1957-2003, the same conclusion can be made on the smelt in the Gulf of Riga. According to Hudd (1985) the growth rate of females somewhat exceeds that of males in the Northern Quark. However, Hudd treats the sexes together in the presentation of smelt growth in the Gulf of Bothnia. Below sexes are combined in growth rate calculations on different stocks of smelt. 
The growth rate declines from south to north. At the end of the first year the length of smelt in the Gulf of Bothnia (Northern Quark) is 5.5-6.5 cm, in the Gulf of Riga 5-9 cm (mean $6.9 \mathrm{~cm}$ ). As shown in Table 3, in 1976 the lengths- and weights-at-age of smelt in the Curonian Lagoon (Gaigalas \& Mištautaite, 1980) exceeded the corresponding values in the Gulf of Riga.

In the Northern Quark the growth rate of smelt differs very little from that of the smelt in the northern Gulf of Bothnia. However, it is slower than in the Gulf of Finland (Voigt, 1972; Hudd, 1985) and, according to our data, also slower than in the Gulf of Riga.

The long-term dynamics of the average length and weight of smelt in spawning concentrations in Pärnu Bay (Gulf of Riga) is shown in Figs. 2 and 3. The size of younger smelt had an increasing tendency during the period 1969-2002. For the length of the three-year-old individuals the trend can be expressed by the equation $y=0.0282 x+15.489\left(R^{2}=0.4482\right)$. However, since the early $1990 \mathrm{~s}$ a tendency of the decrease of weight of older fish has been obvious (Fig. 4). A similar decline of the average weight of older smelt in the Gulf of Finland in the 1990s was noted by Lehtonen et al. (1997).

Table 3. Length- and weight-at-age of smelt in the Curonian Lagoon and the Gulf of Riga

\begin{tabular}{l|c|c|c|c}
\hline \multirow{2}{*}{ Age } & \multicolumn{2}{|c|}{ Curonian Lagoon } & \multicolumn{2}{c}{ Gulf of Riga } \\
\cline { 2 - 5 } & $\mathrm{Fl}, \mathrm{cm}$ & $\mathrm{W}, \mathrm{g}$ & $\mathrm{Fl}, \mathrm{cm}$ & W, g \\
\hline \multirow{2}{*}{3} & 14.6 & 21.3 & 14.4 & 19.8 \\
4 & 18.6 & 48.2 & 16.8 & 33.5 \\
5 & 21.6 & 71.7 & 18.7 & 46.0
\end{tabular}

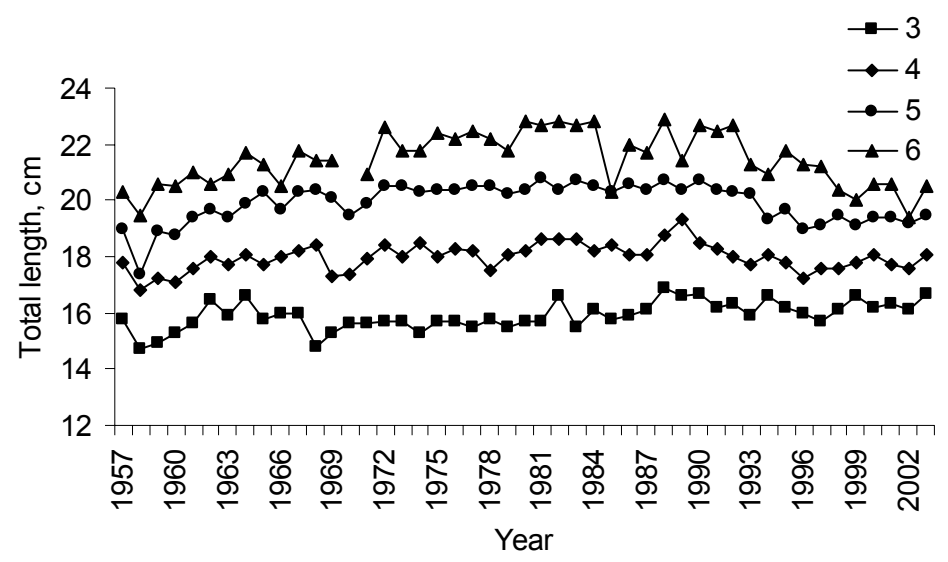

Fig. 2. Mean length of smelt in age groups 3-6 in the Gulf of Riga. 


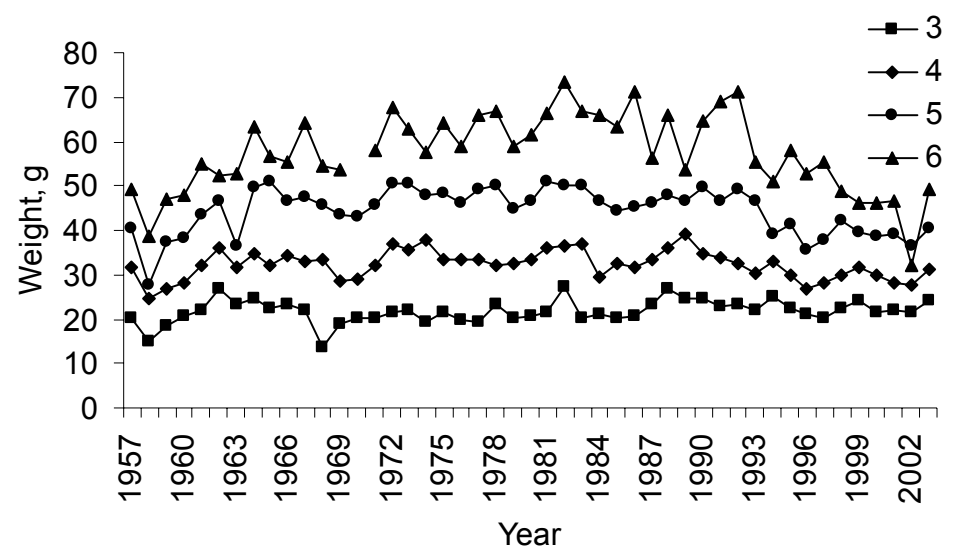

Fig. 3. Mean weight of smelt in age groups 3-6 in the Gulf of Riga.

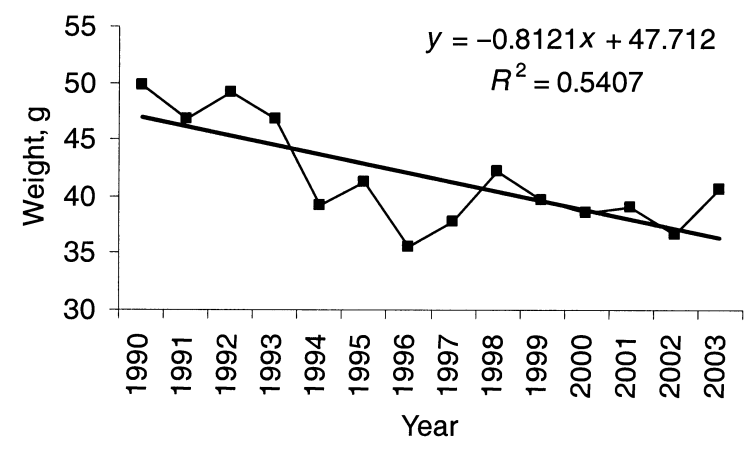

Fig. 4. Mean weight of 5-year-old smelt in the Gulf of Riga.

It is probable that these developments have been caused by changes of the food web, which have been reflected in the availability of food for both younger and older smelt. In general, the importance of eurybionts (Eurytemora hirundoides, Mysis mixta, Neomysis integer) constituting the main food of younger smelt has increased in the Gulf of Riga during the period considered. On the contrary, the importance of cold-water relict species (Limnocalanus grimaldii, Mysis relicta, Monoporeia affinis) has decreased. Compared to the 1960s, the proportion of Pontoporeia femorata, a susceptible species as to its environment, has seriously decreased in the food of smelt. A valuable food item of especially older smelt, P. femorata, constituted $20-25 \%$ in its food in the 1960 s. In the 1980 s its share had diminished to $0.3 \%$ of the weight of smelt food and the animal occurred only deeper than 30 m (Kostrichkina, 1969; Shestakov, 1970; Lagzdinsh et al., 1987; Urtans, 1990). In the 1990s the importance of P. femorata in smelt food was very 
low in the Gulf of Riga. On the other hand, an alien planktonic species Cercopagis pengoi improved the food supply of younger smelt. It constituted up to $6 \%$ by weight in the food of 1-3-year-old individuals in this period.

\section{Abundance dynamics and catches}

There are large variations in smelt year-class abundance, which mainly depends on the mortality rate in the embryonic and larval stage. It has been found that significant negative correlation exists between the water temperature during the embryonic development and the abundance of the year-class (Rannak et al., 1974). Larger smelt populations differ in their year-class abundance. However, the periods of appearance of abundant year-classes from the 1960s to the beginning of the 1970s, and from the end of the 1970s to the middle of the 1980s, and also the periods of moderate/weak year-classes in the 1970s and from the late 1980s to the 1990s, are common for smelt populations both in the Gulf of Riga and Gulf of Finland (Fig. 5). It is probable that the periods of abundant and weak year-classes in the Gulf of Riga and Gulf of Finland have a general background of large-scale changes in the marine ecosystems under the impact of long-term fluctuations in climate.

In the Baltic Sea smelt is important in the food web, especially in the ecological subsystems of the Gulf of Riga, Gulf of Finland, Bothnian Sea, and Bothnian Bay as well as in the Curonian Lagoon. In these areas rather abundant smelt stocks transfer the production of cold-water zooplankton and nektobenthos to salmon, sea trout, and other top predators. Available smelt catch figures do not allow correct long-term comparison of exploitation of the stocks throughout the Baltic Sea. However, it can be stated that the catches largely vary both in time and by sea areas, probably due to differences in the abundance dynamics and exploitation rate of populations (Fig. 6).

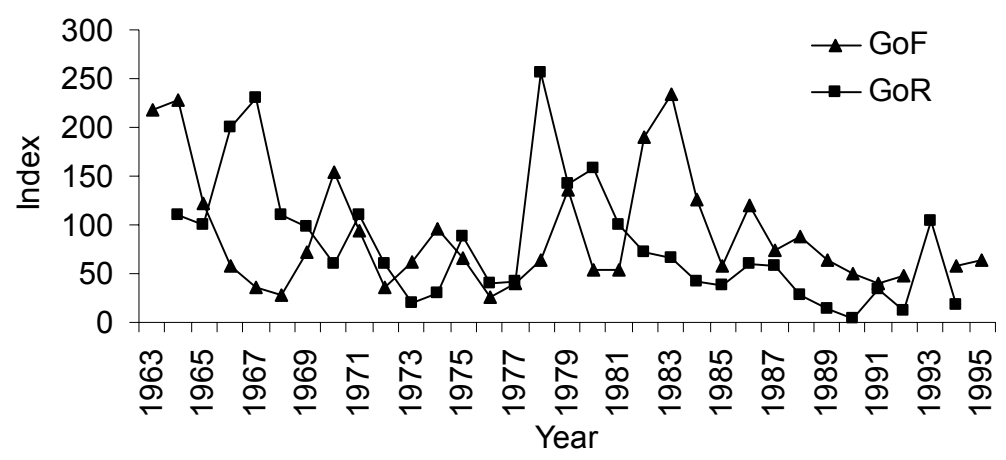

Fig. 5. Smelt year-class index in the Gulf of Finland (GoF, Lehtonen et al., 1997) and Gulf of Riga (GoR, \% of the average year-class abundance in the period 1978-1990) in 1963-1995. 


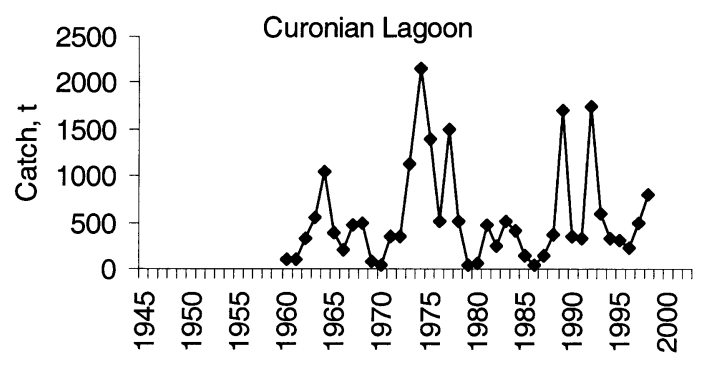

Gulf of Riga
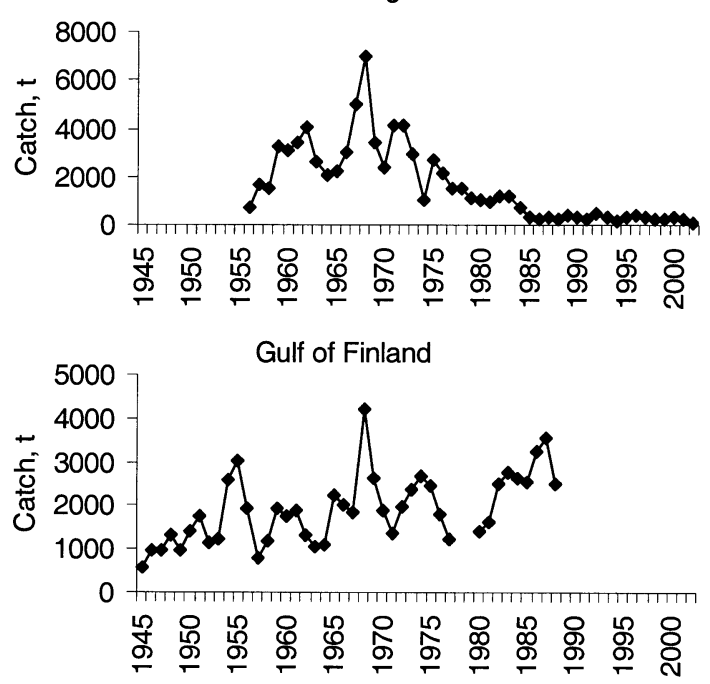

Gulf of Bothnia

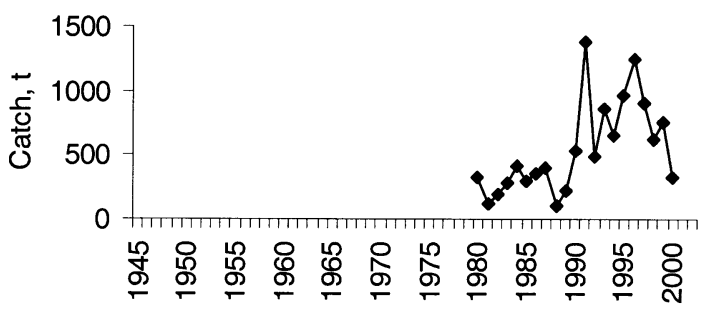

Fig. 6. Smelt catches (tonnes) in various areas of the Baltic Sea (Anon., 2001; Švagždys, 2002; authors' unpubl. data).

\section{ACKNOWLEDGEMENTS}

The authors thank Veera Kople (Shestakov), who collected and treated the material on smelt caught in Estonian waters from 1957 to 1989. The study was partly financed by the Fundamental Science Programme of the Estonian Government (contract 0182579s03). 


\section{REFERENCES}

Anon. 2001. Commercial marine fishery. Finnish Fishery Time Series, pp. 14-44. SVT. Helsinki.

Belyanina, T. 1966. Fecundity of smelt and the factors responsible. In Abundance Dynamics of Fishes of the White Sea Basin, pp. 181-199. Nauka, Moskva (in Russian).

Benecke, B. 1881. Der Stint Osmerus eperlanus eperlanus L. In Fische, Fischerei und Fisch-zucht in Ost- und Westpreussen, pp. 155-157. Königsberg.

Draganik, B. 1997. Effect of river inflow on fish assemblages in the Polish coastal waters. ICES CM 1997/S:05 (mimeo).

Gaigalas, K. S. 1970. Population and catch structure, stock and recruitment of the vimba bream Vimba vimba L. in the Curonian Lagoon. Vopr. Ikhtiol., 10(2), 277-289 (in Russian).

Gaigalas, K. S. \& Mištautaitè, V. 1980. Mean features of ecology and commercial catches of the migratory form of European smelt Osmerus eperlanus (L.) in the Gulf of Kuršyu Mares and the River Nyamunas. Vopr. Ikhtiol., 20(4), 625-634 (in Russian).

Gaumiga, R. 1967. On the role of the Daugava River in recruitment of spring spawning fish stocks. Rybokhozyajstv. Issl. BaltNIIRH, 3, 197-204 (in Russian).

Heinemann, B. 1905. Der Fischfang an der russischen Ostseeküste. In Sonderdruck aus der Landund forstw. Zeitung, 33-42. Riga.

Hudd, R. 1985. Assessment of the smelt (Osmerus eperlanus (L.)) stock in the Northern Quark, Gulf of Bothnia. Finn. Fish. Res., 5, 55-68.

Kostrichkina, E. M. 1969. Feeding and feeding relations of demersal and bentho/pelagic fishes in the Gulf of Riga. Cand. Biol. thesis. Petrozavodsk State University (in Russian).

Kozhevnikov, G. 1949. Biology and ecology of smelt Osmerus eperlanus (L.) in Neva Bay. Cand. Sci. thesis. VNIORH (in Russian).

Kraikovski, A., Lajus, J., Dimitrieva, Z., Karimov, A., Leontiev, P., Merzliakova, I. \& Sukhorukova, A. 2004. The Russian Baltic fisheries on the base of the Russian cadastres of the 16th c. documents: spatial distribution, composition of catches, fishing effort and development tendencies. Report of the Russian HMAP Baltic project 2004.

Lagzdinsh, G., Saule, A. \& Pallo, P. 1987. Zoobenthos of the coastal areas of the Baltic Proper, Gulf of Riga and Gulf of Finland and its zonation. In Hydrochemical and Hydrobiological Characteristics and Zonation of Coastal Areas of the Baltic Sea, Gulf of Riga and Gulf of Finland, pp. 164-181. Zinatne, Riga (in Russian).

Lehtonen, H., Raid, T., Kallio, M., Eero, A., Järv, L., Kaljuste, O., Parmanne, R., Popov, A. \& Shpilev, H. 1997. Long-term trends in fish populations and catches in the Gulf of Finland. In Proceedings of the Final Seminar of the Gulf of Finland Year1996 (Sarkkula, J., ed.), pp. 279-294. Helsinki, Suomen Ympäristökeskus.

Mištautaitè, V. 1973. Morphological and ecological variability of smelt in Lithuanian waters (1. Morphological characteristics and taxonomic position). Tr. Akad. Nauk Lit. SSR, 1(61), 159-174 (in Russian).

Noskova, E. 1968. The biology and abundance fluctuations of smelt (Osmerus eperlanus eperlanus m. spirinchus Pallas) in the Curonian Lagoon of the Baltic Sea. Cand. Sci. thesis. Kaliningrad (in Russian).

Podarueva, Z. 1972a. Fisheries biological characteristics of smelt Osmerus eperlanus (L.) in Neva Bay based on data from 1965-1967. Izv. GosNIORH, 82, 11-34 (in Russian).

Podarueva, Z. 1972b. On the dynamics of fat in smelt of Neva Bay. Izv. GosNIORH, 82, 36-45 (in Russian).

Popov, A. 1977. Morphological characteristics of smelt in the eastern part of the Gulf of Finland. Izv. GosNIORH, 123, 133-137 (in Russian).

Popov, A. 1978. On the peculiarities in maturation of smelt in the eastern Gulf of Finland. Izv. GosNIORH, 129, 37-41 (in Russian).

Popov, A. 1985. Fecundity of smelt in the Gulf of Finland. Tr. GosNIORH, 237, 56-70 (in Russian). 
Pravdin, I.. 1939. The Manual on Investigations on Fish. Leningradskij gosudarstvennyj universitet (in Russian).

Psuty-Lipska, I. \& Garbacik-Wesołowska, A. 1998. Species composition and fish distribution in the Pomeranian Bay and Szczecin Lagoon. Bull. Sea Fish. Inst. (Gdynia), 3(145), 3-20.

Rannak, L., Erm, V., Kople, V. \& Simm, M. 1974. Pärnu Bay as a nursery area of spring spawning herring, smelt and pikeperch. Eesti Loodus, 9, 517-524.

Shestakov, V. 1967. Spawning biology of smelt in Pärnu Bay. Rybokhozyaistv. Issl. BaltNIIRH, 6, 119-128 (in Russian).

Shestakov, V. 1970. Feeding of smelt in Pärnu Bay and the Gulf of Riga. Tr. BaltNIIRH, 4, 349 360 (in Russian).

Shpilev, H. 2003. Smelt (Osmerus eperlanus eperlanus L.). In Fishes of Estonia (Ojaveer, E., Saat, T. \& Pihu, E., eds.), pp. 143-147. Estonian Academy Publishers, Tallinn.

Švagždys, A. 2002. Abundance of ruffe in the Curonian Lagoon and the reasons for changes in their resources. Zuvininkyste Lietuvoje IV (Vilnius), 177-188.

Urtans, E. 1990. Feeding of smelt (Osmerus eperlanus L.) and eelpout (Zoarces viviparus L.) in the Gulf of Riga. Fischerei-Forschung, 2, 34-38 (in Russian).

Voigt, H. 1972. Bidrag till kännedom om brackvattennorsens biologi. Norsen (Osmerus eperlanus L.) i Tvärminne som exempel. University of Helsinki (mimeo).

Winkler, H. M. 1996. Peculiarities of fish communities in estuaries of the Baltic Sea; the DarssZingst-Bodden chain as an example. Limnologica, 26(2), 199-206.

\section{Meritint (Osmerus eperlanus L.) Läänemeres}

\section{Heli Shpilev, Evald Ojaveer ja Ain Lankov}

Läänemeres asuvad külmaveelise anadroomse meritindi peamised asurkonnad rannikumere üksteisest suhteliselt eraldatud lahtedes: Botnia lahes, Soome lahe idaosas, Liivi lahes ning Kura lõukas. Mere süvaveelises avaosas meritinti ei leidu. Meritindi populatsioonid on üksteisest eraldatud ja eksisteerivad erinevates tingimustes, millest tulenevad ka erisused morfomeetrilistes ja kasvuparameetrites ning ka kudemisajas. Meritindi kasvukiirused Läänemeres langevad lõunast põhja suunas. Alates 1990. aastatest on meritindi keskmine kaal vanemates vanuserühmades langenud.

Meritindi populatsioonidünaamika ja töönduslikud saagid on asurkonniti erinevad, kõikudes laiades piirides. 